\title{
SOCIAL SCIENCE
}

International Journal of Environmental, Sustainability, and Social Sciences

ISSN 2720-9644 (print); ISSN 2721-0871 (online)

https://journalkeberlanjutan.com/index.php/ijesss

Volume 1

Nomor 1

March 2020

Page 70-76

\section{Article History:}

Received: 2020-03-10

Revised: 2020-03-25

Accepted: 2020-03-30

\section{DETERMINANTS OF ACCOUNTING INFORMATION SYSTEM IN PT. INDOMARCO ADI PRIMA, JEMBER BRANCH}

1 Rina Dian AGUSTIN, ${ }^{2}$ Muhammad FIRDAUS, ${ }^{3}$ Nanda WIDANINGGAR

${ }_{1}$ Student of Accounting Department, STIE Mandala Jember, Indonesia.

${ }^{2}$ Associate Professor at the Department of Magister Management, STIE Mandala Jember, Indonesia.

${ }^{3}$ Lecturer in the Department of Accounting, STIE Mandala Jember, Indonesia.

Corresponding author: Muhammad Firdaus

Associate Professor at the Department of Magister Management, STIE Mandala Jember

E-mail: muhammadfirdaus2011@gmail.com

\begin{abstract}
:
The fundamental role of Accounting Information Systems (AIS) in organizations was a processor of accounting data to produce quality accounting information to support the company's internal activities, which had a significant correlation with the external. By the purposive sampling method, this study aims to analyze the impact of Education and Training Programs, Involvement of System Users, and Human Resources (HR) Competence on the Quality of Accounting Information Systems at PT. Indomarco Adi Prima Jember Branch, since there were ineffective process in selling application, by the late of manager approval and the network problem. The population in this study were all of employees who use Information Systems at PT. Indomarco Adi Prima Jember Branch. The method used was multiple regression, the data collection technique was questionnaire, and the result showed that the variable Education and Training Program significantly influences the quality of the AIS, System User Involvement variable significantly influences the quality of SIA, and HR competency variable significantly influences the quality of SIA and the coefficient of determination $\left(\mathrm{R}^{2}\right)$ of all independent variables strongly explained the dependent variable.
\end{abstract}

\section{Keyword:}

Education and Training Programs, System Users Involvement, Human Resources Competence, Quality of Accounting Information System.

Cite this as Agustin, R.D., Firdaus, M., Widaningsih, N (2020). Determinants of Accounting Information System in PT. Indomarco Adi Prima, Jember Branch. International Journal of Environmental, Sustainability, and Social Science, 1(1), 70-76. https://doi.org/10.38142/ijesss.v1i1.48

\section{INTRODUCTION}

Information technology is currently developing very fast. The involvement of Information Technology in the development of Information Systems is very necessary to support company performance. The system is a collection of objects or elements or parts that have different meanings that are interrelated, cooperate and influence one another and have an attachment to the same plan or plan in achieving a particular goal in a complex environment. Information is data that has been processed so that it can be useful for anyone who needs it. In computer science, information is data that is stored, processed or transmitted. ((Bodnar, H. \& Hopwood, 2000): 1), in their research on the notion of information is useful data that is processed in such a way that can be used as a basis for making the right decision. Information is also data that is further processed so that it has meaning for the recipient and has a "value of influence" for actions, decisions now or in the future. So the understanding between each data and information must be distinguished. Then it can be explained that the data is the raw material of information that is defined as a group of certain symbols that have a meaning of quantity, actions, objects and so on (Ives \& Olson, 1994). Information system is a component that consists of people, information technology, and work procedures that process, store, analyze, and disseminate information to achieve a goal. Information systems have become a necessity for companies because they are expected to be able to support decisions in creating efficiency, improving performance, and ultimately will be able to serve customers according to their wants and needs. Initially Information Systems are very useful for companies in terms of data collection, data storage, even to the management of data, as an integral part of the decision making system. However, today an Information System contributes to the identification of problems and business forecasting in the future (Widaninggar, 2013): 306-307). Information systems were very important in the decision making process, therefore information is needed that is relevant to the needs of the organization ((Romney \& Steinbart, 2012): 25). Information that is managed effectively within an organization will be very important because it can be the 


\section{SOCIAL SCIENCE}

\section{International Journal of Environmental, Sustainability, and Social Sciences ISSN 2720-9644 (print); ISSN 2721-0871 (online) \\ https://journalkeberlanjutan.com/index.php/ijesss}

basis for gaining competitive advantage. In addition, well-managed information can be used to increase other company resources. Information system is a system within an organization that meets the needs of daily transaction processing, supports operations, it is managerial and strategic activities of an organization and provides certain external parties with the necessary reports. (O'brien \& Marakas, 2010): 4) said that the Information System is a combination of each unit managed by a user or human, hardware, software, computer networks and data communication networks (communication), and also databases that collects, changes and disseminates information about an organization. So, basically Information Systems must have these elements in order to be useful and work optimally. Information Systems consist of five resources known as Information Systems components. The five resources are human, hardware, software, data and network. These five components play an important role in an Information System. However, in reality, not all Information Systems include the five components. For example, personal information systems that do not cover telecommunications networks.

Accounting Information System is a very important part in a company's Information System. In a company, Accounting Information System is a part of the Information System that is more related to financial data. According to (Widjajanto, 2001): 14), Accounting as an Information System includes the activities of identifying, gathering, processing, and communicating economic information about an organization to various parties. Accounting Information System is a framework for coordinating resources (data, materials, equipment, suppliers, personal, and funds) to convert inputs in the form of economic data into outputs in the form of financial information used to carry out an entity's activities and provide accounting information for parties have an interest. Accounting Information System (AIS) is a structure that is united in organizational entities that employ resources and other components to convert economic data into accounting information with the aim of satisfying the information needs of users. Integration (collection) of sub-systems/components both physical and non-physical that were interconnected and work together in harmony to process transaction data related to financial problems into financial information ((Susanto, 2013): 72). The fundamental role of Accounting Information Systems (AIS) in organizations as a reservoir and processor of accounting data to produce quality accounting information to support the company's internal activities carried out by managers and employees as well as the company's internal activities with external parties such as with consumers, suppliers, government and others (Susanto, 2013): 374). (Widaninggar, 2013) said that information system was needed by the company because it was some kind of tool that support the company efficiency, performance and to meet the customer need. AIS has a large contribution to identify the company's problems and to predict the future problems of the company.

The quality of system is a measurement of Information Systems processes that focus on the results of interactions between users and systems. The quality of the system has attributes such as equipment availability, equipment reliability, ease of use, and response time are determining factors why an Information System is used or not used. (Delone \& McLean, 2003)) stated that System Quality is a measurement of technical success, Information Quality is a measure of semantic success, user satisfaction illustrates the influence of individuals and organizations which is a measure of success effectiveness. Information Quality is the level at which a data that has been processed by the Information System has meaning for its users, which can be in the form of facts and a useful value. In PT. Indomarco Adi Prima, Jember Branch, there were disturbing problems for the users of company's Accounting Information System. AIS should have a large contribution in efficiency, but the selling data system cannot support that, because the late transaction approval from the manager and the bad network quality from the company provider. Some of the research that has been done were (Komara, 2006), which stated that involvement of users, size of organization, support of top management, formalization had a significant impact on users' satisfaction, but capability had no significant impact. This result was in line with research conducted by (McKeen, Whetherbe, \& James, 1992) and (Restuningdiah, Nurika, \& Indriantoro, 2000) which said that users' involvement impact the users' satisfaction. Research conducted by (Sukmaningrum, 2012), the results showed that the internal control system has a significant effect on the quality of local government financial statement information, while HR competency is not significant due to the lack of HR itself in terms of quality and quantity. (Malle, 2016) stated that HR Competency has a significant effect on the quality of information on the Makassar City government's financial statements while the internal control system and regional financial supervision does not affect the quality of the Makassar City Government's financial statement information. Research conducted by (Gustiyan, 2014), showed that only the User Involvement variable and the Information System User Training and Education Program alone have significant influence on the performance of the Accounting Information System while the other variables have no effect and were not significant on the AIS performance. Research of (Samosir, 2018)) concluded that the influence of HR Competence and internal control systems on the quality of local government financial reports as well as the moderating variables. (Fasihat, 2015) stated that there was no significant effect between the quality of the AIS and company performance with a probability of 0.089 which was thought to occur because BPD DIY Syariah was still under the auspices of the Central DIY BPD, where activities that affect performance improvement were directly determined by center.

There were several factors that can affect the quality of AIS including Education and Training Programs, System Users Involvement' and HR Competency. By education and training, users can gain the ability to identify their information requirements and the seriousness and limitations of this Information System and capabilities can lead to improved performance. With the existence of a system user training program can use the existing system in the company properly, it has an important effect on the survival of 


\section{SOCIAL SCIENCE}

\section{International Journal of Environmental, Sustainability, and Social Sciences ISSN 2720-9644 (print); ISSN 2721-0871 (online) \\ https://journalkeberlanjutan.com/index.php/ijesss}

the company. In the design and development of Information Systems System User Involvement is emphasized more on how the role of the user in the information system design process and what steps were taken in supporting and directing its contribution, while the intended user support for the design and development of AIS is related to direction conducted by the user when the Information System is operated, one of which is to use computers effectively. Information system by involving users will give satisfaction to the users and those users will be willing to use the AIS applied in the company. If the user is given the opportunity to provide opinions and proposals in the development of the Information System, then the user feels that the Information System is his responsibility, so expect the Quality of the Information System to improve. Human Resources is a factor that influences the readiness and effectiveness of the implementation of the Accounting System. Competence is the knowledge and expertise needed to complete a task. Adequate HR competency in terms of quantity and quality will increase the value of information in a report.

A good information system needs to be well prepared and planned. The manager in charge of the functional information system unit, called the Chief of Information Officer (CIO) is responsible for managing the unit and information resources properly and providing information services to their users at an agreed service level. As a service department, CIOs must provide the best technical staff (information systems experts) to be able to provide Information Systems service support to users of information services in a high level of user satisfaction. Information System Products for support and fulfillment of user needs must be reliable to meet the needs and satisfy.

Accounting Information System is basically an integration of various transaction processing systems (SPT) or sub SIAs. Because every SPT has a transaction processing cycle, SIA can be said to be an integration of various transaction processing cycles ((Susanto, 2013):72). In every processing it does, the SPT or sub-SIA uses various components it has, such as hardware, software, brainware, procedures, databases and communication networks ((Susanto, 2013):72). The integration of the components mentioned above is a company's information resources in order to achieve substantial excellence ((McLeod \& Schell, 2007):29). SIA was built with the main objective to process accounting data from various sources into accounting information needed by various users to reduce risks when making decisions ((Susanto, 2013): 8), the application of Quality SIA will produce Quality Accounting Information that is also used by users in making decisions. In measuring the quality of the AIS is influenced by several factors including Education and Training Programs, System User Involvement, and Human Resource Competency.

The user education and training program is a process of education within a certain period that teaches new employees and current employees a basic skill that will be used to help carry out their work and achieve company goals. In the case of the development of an existing Information System in a company, the Education and Training Program is very influential for the company in determining the quality or performance of the system, with education and training users can get the ability to identify their information requirements and the seriousness and limitations of the Information System and this ability can leads to improved performance ((Montazemi, 1988)). The purpose of having an Education and Training Program in the company is to provide direction to System users/employees to use the system properly, and with the existence of an Education and Training Program the company hopes to be able to direct improvements to the Quality of the existing System. Information system by involving users will give satisfaction to the users and those users will be willing to use the AIS applied in the company. If the user is given the opportunity to provide opinions and proposals in the development of the Information System, then the user feels that the Information System is his responsibility, so expect the Quality of the Information System to improve. Human Resource (HR) in an organization or company has the same importance as the work itself, given the important role of HR in the organization or company, HR as a determining factor for the organization, so competency is an aspect that determines the success of the organization or company. With high competency possessed by HR in the company, of course this will determine the quality of human resources that will ultimately determine the competitive quality of the company itself. Based on the background stated, this research is aimed at 1) analyzing the influence of the Education and Training Program, Involvement of System Users, and HR Competency on SIA Quality at PT. Indomarco Adi Prima Jember Branch. 2) analyze the ability of independent variable variation models in explaining the dependent variable, and the research was developed by three hypothesis': Effects of Education and Training Programs on SIA Quality, Effect of involvement of system users on the quality of the AIS, and Effect of HR Competency on Quality of AIS.

With education and training users can get the ability to identify their information requirements and the seriousness and limitations of the Information System and this ability can lead to improved performance (Montazemi, 1988). Research conducted by (Gustiyan, 2014), showed that only the User Involvement variable and the Information System User Training and Education Program alone have significant influence on the performance of the Accounting Information System while the other variables have no effect and were not significant on the AIS performance. User involvement in the development of the system is predicted to develop or improve the quality of the system by providing a more accurate and complete research on user information requirements. Many researchers have investigated user involvement. They believe that involvement influences key criteria such as system quality, user satisfaction and system use ((Ives $\&$ Olson, 1994); (Hirschheim, 1985); (Nelson \& Cheney, 1987)). They believe that user involvement in the system development process has a positive influence on satisfaction with the Computerize Based Information System (CBIS). This result support the research conducted by (Hirschheim, 1985), (Nelson \& Cheney, 1987). (Huff \& Munro, 


\section{SOCIAL SCIENCE}

\section{International Journal of Environmental, Sustainability, and Social Sciences ISSN 2720-9644 (print); ISSN 2721-0871 (online) \\ https://journalkeberlanjutan.com/index.php/ijesss}

in (Soegiharto, 2001) which also found that the capability of AIS' personnel had an impact on design quality and the performance of Information System. HR competency were abilities possessed by a person related to knowledge, skills and personality characteristics that directly affect the performance that can achieve the desired goals. In line with that assumption, (Choe, 1996) found thar there was positive correlation between AIS' personnel capability and the use of system. Research of (Samosir, 2018)) concluded that the influence of HR Competence and internal control systems on the quality of local government financial reports as well as the moderating variables. (Sukmaningrum, 2012) stated that the internal control system has a significant effect on the quality of local government financial statement information, while HR competency is not significant due to the lack of HR itself in terms of quality and quantity. (Malle, 2016) stated that HR Competency has a significant effect on the quality of information on the Makassar City government's financial statements while the internal control system and regional financial supervision does not affect the quality of the Makassar City Government's financial statement information.

\section{METHOD}

The population in this research is the area that the researcher wants to study. According to (Sugiyono, 2014:80), population is a generalization area consisting of objects/subjects that have certain qualities and characteristics determined by researchers and then conclusions are drawn. The population in this study were all staff/employees of PT. Adiarco Adi Prima, Jember Branch, amounting to 150 employees in 2019.

Samples are part of the population to be investigated. According to (Sugiyono., 2014:81). The sample in this study used a purposive sampling technique. The purposive sampling is a data source sampling technique with certain considerations (Sugiyono., 2014:85). The reason for using a purposive sampling technique is because not all samples have criteria in accordance with the phenomenon being studied. Therefore, the researcher chooses the technique purposive sampling which sets certain considerations or criteria that must be met by the samples used in this study. The criteria used as samples include (1) Status of active and permanent employees; (2) Employees who work more than one year, (3) Employees working at PT Indomarco Adi Prima Jember Branch who use AIS include IT/EDP, Controller, Administration, Finance, Accounting, Logistics, HRD, and Warehouse Staff.

Table 1. Sample Determination

\begin{tabular}{clc}
\hline No & \multicolumn{1}{c}{ Information } & Total Employees \\
\hline 1 & Active employee and permanent employees & 150 \\
2 & Employees working less than 1 year & 90 \\
3 & Employees who work do not use Accounting Information & 25 \\
& Systems $\quad$ Total Samples & 35 \\
\hline
\end{tabular}

Source: PT. Indomarco Adi Prima Jember Branch

The method of data collection that will be carried out in research is by conducting field surveillance by directly observing the object of research. Data collection techniques used in this study are questionnaires. The measurement scale used in this study is the Likert scale. Likert scale is used to measure the attitudes, opinions, and perceptions of a person or group of people about social phenomena, where this phenomenon has been specifically determined by researchers hereinafter referred to as the research variable. Questions are given in stages, starting from the lowest level to the highest level.

Data analysis methods used in this study, data quality tests namely, 1) validity and reliability tests, 2) classic assumption tests include normality tests, multicollinearity tests, heteroscedasticity tests, 3) multiple linear regression analysis, 4) hypothesis testing using tests t-test, and 5) the coefficient of determination ( $\left.\mathrm{R}^{2}\right)$. Analysis of the data in this study using SPSS software.

\section{RESULTS AND DISCUSSION}

The results of the analysis in this study were obtained as follows:

\section{1) Data Quality Test}

The data quality test of validity and reliability, as shown on Table 2 and Table 3:

Table 2. Test of Validity

\begin{tabular}{ccccc}
\hline Variable & Item Questions & $\begin{array}{c}\text { Corrected Item } \\
\text { Total Questions } \\
\text { Correlation }\end{array}$ & r table & Description \\
\hline Education and & $\mathrm{X} 1.1$ & 0,394 & 0,334 & Valid \\
Training & $\mathrm{X} 1.2$ & 0,512 & 0,334 & Valid \\
Program $\left(\mathrm{X}_{1}\right)$ & $\mathrm{X} 1.3$ & 0,361 & 0,334 & Valid \\
& $\mathrm{X} 1.4$ & 0,724 & 0,334 & Valid \\
\hline
\end{tabular}




\section{SOCIAL SCIENCE}

International Journal of Environmental, Sustainability, and Social Sciences

ISSN 2720-9644 (print); ISSN 2721-0871 (online)

https://journalkeberlanjutan.com/index.php/ijesss

\begin{tabular}{ccccc}
\hline \multirow{2}{*}{$\begin{array}{c}\text { System User } \\
\text { Engagement }\left(\mathrm{X}_{2}\right)\end{array}$} & X1.5 & 0,768 & 0,334 & Valid \\
& X2.1 & 0,744 & 0,334 & Valid \\
& X2.3 & 0,901 & 0,334 & Valid \\
& X2.5 & 0,798 & 0,334 & Valid \\
X3.1 & 0,688 & 0,334 & Valid \\
HR Competency & X3.2 & 0,896 & 0,334 & Valid \\
X3.3 & X3.4 & 0,75 & 0,334 & Valid \\
& X3.5 & 0,697 & 0,334 & Valid \\
Quality of AIS (Y) & Y1.1 & 0,592 & 0,334 & Valid \\
& Y1.2 & 0,554 & 0,334 & Valid \\
& Y1.3 & 0,701 & 0,334 & Valid \\
& Y1.4 & 0,629 & 0,334 & Valid \\
\hline
\end{tabular}

Table 3. Test of Reliability

\begin{tabular}{cccc}
\hline Variable & $\begin{array}{c}\text { Reliability } \\
\text { Coefficients }\end{array}$ & Alpha & Information \\
\hline Education and Training Program & 5 Item & 0,700 & Reliable \\
$\left(\mathrm{X}_{1}\right)$ & 5 Item & 0,801 & Reliable \\
System User Engagement $\left(\mathrm{X}_{2}\right)$ & 5 Item & 0,782 & Reliable \\
HR Competency $\left(\mathrm{X}_{3}\right)$ & 5 Item & 0,795 & Reliable \\
Quality of AIS & & \\
\hline
\end{tabular}

\section{Classical Assumption Test}

- Testing the normality of data in the study using the Kolmogorov-Smirnov One Sample test, resulting in Kolmogrov-Smirnov $Z$ of 0.464 with a significance level of 0.982 . This shows that the research variables are normally distributed because they are at a significant level> 0.05 .

- The results of multicollinearity testing carried out are known that the value of Variance Inflation Factor (VIF) of Education and Training Program variables, System User Involvement, and HR Competencies are less than 10 and Tolerance values greater than 0.10 , so it can be assumed that there is no multicollinearity between independent variables in the regression model.

- Testing heteroscedasticity using scatterplot graphs, the results show that there are clear patterns and points that spread above and below the number 0 on the $\mathrm{Y}$ axis. So it can be concluded that there is no heteroscedasticity in the regression model. This shows that all independent variables can be used to predict SIA quality.

\section{Multiple Regression Analysis}

In this research, multiple linear regression analysis aims to explain the magnitude of the influence of the Education and Training Program, System User Involvement, and HR Competencies on SIA Quality. The following table was linear regression analysis to test the hypotheses in the study.

Table 4. Linear Regression Analysis

\begin{tabular}{|c|c|c|c|c|c|}
\hline \multirow[t]{2}{*}{ Model } & \multicolumn{2}{|c|}{$\begin{array}{l}\text { Unstandardized } \\
\text { Coefficients }\end{array}$} & \multirow{2}{*}{$\begin{array}{c}\text { Standardized } \\
\text { Coefficients } \\
\text { Beta }\end{array}$} & \multirow[t]{2}{*}{$\mathbf{T}$} & \multirow[t]{2}{*}{ Sig. } \\
\hline & B & Std. Error & & & \\
\hline (Constant) & 9.411 & 2.164 & & 4.349 & .000 \\
\hline Education and Training Program $\left(\mathrm{X}_{1}\right)$ & .540 & .178 & .594 & 3.030 & .005 \\
\hline System User Engagement $\left(\mathrm{X}_{2}\right)$ & -.472 & .182 & -.452 & -2.593 & .014 \\
\hline HR Competency $\left(\mathrm{X}_{3}\right)$ & .429 & .120 & .588 & 3.568 & .001 \\
\hline a. Dependent Variable: $\mathrm{Qu}$ & AIS (Y) & & & & \\
\hline
\end{tabular}

So that the regression equation is obtained as follows:

$$
\mathrm{Y}=9,411+0.540 \mathrm{X} 1-0.472 \times 2+0.429 \times 3
$$




\title{
SOCIAL SCIENCE
}

\author{
International Journal of Environmental, Sustainability, and Social Sciences \\ ISSN 2720-9644 (print); ISSN 2721-0871 (online) \\ https://journalkeberlanjutan.com/index.php/ijesss
}

The equation showed that:

1. $Y=$ SIA quality equal to constant $=9,411$ if the value of the independent variable (Education and Training Program, System User Involvement, and HR Competency) is 0, this can be explained that there is already SIA Quality even though there is no Education and Training Program, User Involvement Systems, and HR Competencies.

2. If all other variables are constant then an increase in the Education and Training Program will result in an increase in the quality of the AIS.

3. If all other variables are constant then an increase in System User Engagement will result in a decrease in the quality of the AIS.

4. If all other variables are constant then an increase in HR Competency will result in an increase in the quality of the AIS.

\section{Hypothesis Test (t-test)}

Hypothesis t-test results Obtained results (a) Education and Training Program variables have a significance level of $0.005<0.05$, which means that Education and Training Program variables have a significant effect on the Quality of AIS, (b) System User Involvement has a significance level of $0.014>0.05$ which means that the System User Engagement variable significantly influences the SIA Quality, and (c) HR Competency has a significance level of $0.001<0.05$, which means that the HR Competency variable has a significant effect on the SIA Quality.

\section{Determination Coefficient $\left(\mathbf{R}^{2}\right)$}

\section{Table 5. Determination Coefficient}

\begin{tabular}{lcrrr}
\hline \multicolumn{1}{c}{ Model } & $\mathbf{R}$ & R Square & Adjusted R Square & Std. Error of the Estimate \\
\hline 1 & $0.807^{a}$ & 0.651 & 0.617 & 1.196 \\
a. Predictors: (Constant), Education and Training Program $\left(\mathrm{X}_{1}\right)$, System & \\
User Engagement $\left(\mathrm{X}_{2}\right), \mathrm{HR}$ Competency $\left(\mathrm{X}_{3}\right)$ & \\
\hline
\end{tabular}

By the result of regression calculation (see Table 5) can be seen that the coefficient of determination obtained by 0.651 . This means that $65.1 \%$ of the quality of the AIS can be explained by the Education and Training Program, System User Involvement, and HR Competency, while the remaining 0.349 or $34.9 \%$ is explained by other variables not used in this study.

\section{Effects of Education and Training Programs on SIA Quality}

Based on the results of the regression test through the test (t-test) it can be seen that the Education and Training Program factor is $0.005<0.05$, which means that the Education and Training Program factor has a significant effect on the Quality of the AIS. Then the hypothesis $\mathrm{H}_{1}$ is accepted and $\mathrm{H}_{0}$ is rejected. This can be seen from the respondents' answers, the respondents felt agree with the statement that 'with the Education and Training Program can provide direction to employees who use the Information System in PT. Indomarco Adi Prima Jember Branch and Education and Training Program are important for the development of the system to support the company's work operations in order to achieve its objectives.

The results of this test are consistent with (Holmes \& Nicholls, 1988) research showing that formal training influences the preparation of accounting information. Research of (Gustiyan, 2014)) shows that the System User Education and Training Program has a significant effect on the performance of the AIS and other researchers have proposed a positive relationship between user training, user attitudes and the success of the Information System.

\section{Effect of involvement of system users on the quality of the AIS}

Based on the results of the regression test through the test (t-test), it can be seen that the System User Engagement factor is 0.014>0.05, which means the System User Engagement factor significantly influences the SIA Quality. So for the hypothesis $\mathrm{H}_{2}$ accepted and $\mathrm{H}_{0}$ rejected. This can be known from the answers of respondents, respondents felt agree with the statement that the level of participation of employees/users of Information Systems at PT. Indomarco Adi Prima Jember Branch in the development of the system is very high, and employees are satisfied with the Quality of Information Systems in the company, and employees/users are proficient in operating the System. So that the System User Involvement factor has an important influence on the quality of SIA at PT. Indomarco Adi Prima Jember Branch.

The results of this study are consistent with research conducted by (Gustiyan, 2014) which states that the involvement of system users significantly influences the performance of the AIS. Many researchers have investigated user involvement. They believe that involvement influences key criteria such as system quality, user satisfaction and system use ((Ives \& Olson, 1994)) and (Hirschheim, 1985)). They believe that user involvement in the system development process has a positive influence on satisfaction with the Computerize Based Information System (CBIS). 


\title{
SOCIAL SCIENCE
}

\author{
International Journal of Environmental, Sustainability, and Social Sciences \\ ISSN 2720-9644 (print); ISSN 2721-0871 (online) \\ https://journalkeberlanjutan.com/index.php/ijesss
}

\section{Effect of HR Competencies on SIA Quality}

Based on the results of the regression test through the test ( $t$-test) it can be seen that HR Competency factor is 0.001>0.05, which means HR Competencies factor significantly influences the SIA Quality. So for the hypothesis H3 is accepted and HO is rejected. This can be known from the answers of respondents, respondents felt agree with the statement that they understand the clear role and function in developing the Information System and they work based on guidelines regarding the Information System process in the company. The results of this study are consistent with research from (Malle, 2016)) which states that HR Competencies has a significant effect on the quality of information on the Makassar City government's financial statements.

\section{CONCLUSION}

The three variables used in this study affect the quality of the AIS, (1) the variable Education and Training Program significantly influences the quality of the AIS, with education and training, users can get the ability to identify their information requirements and the seriousness and limitations of the System This information and capability can lead to improved performance. With the existence of a system user training program can use the existing system in the company properly, it has an important effect on the survival of the company. (2) System User Engagement variable significantly influences the SIA Quality, in the design and development of Information Systems Involvement of System Users is more emphasized on how the role of the user in the process of designing the Information System and what steps are taken in supporting and directing its contribution, while what is meant by user support for the design and development of the AIS is related to the direction made by the user when the Information System is operated, one of which is to use a computer effectively. Information systems involving users will provide satisfaction for users and those users will be willing to use the AIS applied in the company. If the user is given the opportunity to provide opinions and proposals in the development of the Information System, then the user feels that the Information System is his responsibility, so expect the Quality of the Information System to improve. (3) HR competency variable significantly influences the quality of SIA, so competence is needed within the company, with adequate competence in terms of quantity and quality will increase the content of information in a report. For subsequent studies, it can find other factors that affect the quality of the AIS, for example internal control and researcher not only use questionnaires to collect data, but be followed by interviews with respondents so that respondents' answers reflect the actual answers in a better way.

\section{REFERENCE}

Bodnar, H., W., \& Hopwood, S. (2000). Sistem Informasi Akuntansi. Buku I, Penerjemah Amir Abadi Jusuf dan Rudi M Tambunan (6th ed.). Jakarta: Salemba Empat.

Choe, J. M. (1996). The Relationships Among Performance of Accounting Information Systems, Influence Factors, and Evolution Level of Information Systems. Journal of Management Information System/Spring, 12(4), 215-239. Retrieved from https://www.tandfonline.com/doi/abs/10.1080/ 07421222.1996.11518107. Accessed on January 1, 2020

Delone, W. H., \& McLean, E. R. (2003). Information Systems Success: The Quest for the Dependent Variable. Information System Research, 60-95. Retrieved from https://pdfs.semanticscholar.org/ a041/45f1ca06c61f5985ab22a2346b788f343392.pdf. Accessed on Desember 2, 2019

Fasihat, D. U. (2015). Pengaruh Kualitas Sistem Informasi Akuntansi terhadap Kinerja Perusahaan di Bank Pembangunan Daerah Daerah Istimewa Yogyakarta (BPD DIY) Syariah. Universitas Islam Negeri Sunan Kalijaga Yogyakarta. Retrieved from http://digilib.uin-suka.ac.id/15660/1/BAB I\%2C IV \%2C DAFTAR PUSTAKA.pdf. Accessed on October 3, 2019

Firdaus, M. (2019). Ekonometrika Suatu Pendekatan Aplikatif. Jakarta: Bumi Aksara.

Gustiyan, H. (2014). Analisis Faktor-faktor yang Mempengaruhi Kinerja Sistem Informasi Akuntansi pada Bank Perkreditan Rakyat (BPR) di Tanjungpinang. Universitas Maritim Raja Ali Haji Tanjung Pinang. Retrieved from http://jurnal.umrah.ac.id/wp-content/uploads/gravity_forms/1ec61c9cb232a03a96d0947c6478e525e/2014/08/JURNAL-Hary-Gustiyan-090462201371Akuntansi.pdf. Accessed on October 3, 2019

Hirschheim. (1985). Information Systems Epistemologi: An historical perspective. In Research Methods in Information System (pp. 13-35). Retrieved from https://ifipwg82.org/sites/ifipwg82.org/files/ Hirschheim_0.pdf. Accessed on March 21, 2020

Holmes, S., \& Nicholls, D. (1988). An Analysis of The Use of Accounting Information by Australian Small Business. Journal of Small Business Management, 26(20), 57-68. Retrieved from https://www.econbiz.de/Record/an-analysis-of-the-use-of-accounting-information-by-australian-smallbusiness-holmes-scott/10003580577. Accessed on July 8, 2019

Huff, S. L., \& Munro, M. C. (1985). Information Technology Assessment and Adoption : A Field Study. MIS Quarterly, 9(4), 229-309. Retrieved from https://misq.org/information-technology-assessment-andadoption-a-field-study.html. Accessed on March 21, 2020

Ives, \& Olson. (1994). The Relationship Btween User Participation and User Satisfaction: An Investigation of 


\section{SOCIAL SCIENCE}

\section{International Journal of Environmental, Sustainability, and Social Sciences ISSN 2720-9644 (print); ISSN 2721-0871 (online) \\ https://journalkeberlanjutan.com/index.php/ijesss}

Four Contingency Factors. MIS Quarterly, (December). Retrieved from https://www.academia.edu/19852102/The Relationship between User Participation and User Satisfaction An Investigation of Four Contingency Factors. Accessed on July 8, 2019

Komara, A. (2006). Analisis Faktor-Faktor yang Mempengaruhi Kinerja Sistem Informasi Akuntansi. Jurnal Maksi, 6(2), 143-160. Retrieved from https://ejournal.undip.ac.id/index.php/maksi/article/ view/252. Accessed on March 21, 2020.

Malle, S. S. (2016). Analisis Faktor-Faktor yang Mempengaruhi Kualitas Informasi Keuangan Pemerintah Kota Makassar. UIN Alauddin Makassar. Retrieved from http://repositori.uin-alauddin.ac.id/1250/1/ Syarif Syahrir Malle.pdf. Accessed on July 8, 2019

McKeen, J., Whetherbe, T. G., \& James, C. (1992). The Relationship Between Participation and User Satisfaction of Four Contigency Factors. MIS Quarterly. ABI/ INFORM Global. Retrieved from https://www.academia.edu/19852102/The Relationship between User Participation and User Satisfaction An Investigation of Four Contingency Factors. Accessed on March 21, 2020

McLeod, \& Schell. (2007). Management Information System. New Jersey: Pearson Prentice Hall.

Montazemi. (1988). Factors Aftecting Information Satisfaction in the Context of the Small Business Environment. Mis Querterly, 12(2), 239-256. Retrieved from https://misq.org/factors-affectinginformation-satisfaction-in-the-context-of-the-small-business-environment.html. Accessed on July 8, 2019

Nelson, R. R., \& Cheney, P. H. (1987). Training and Users : An Exploratory Study. MIS Quarterly, 547-559. Retrieved from https://pdfs.semanticscholar.org/1bf9/77ca584b1e07309aa9956e1 15915da508a30.pdf. Accessed on March 21, 2020

O’brien, J. A., \& Marakas, G. M. (2010). Introduction to Information Systems. New York: McGraw-Hill Comparies, Inc.

Restuningdiah, Nurika, \& Indriantoro, N. (2000). Pengaruh Partisipasi terhadap Kepuasan Pemakai dalam Pengembangan Sistem Informasi dengan Kompleksitas Tugas, Kompleksitas Sistem, dan Pengaruh Pemakai sebagai Moderating Variable. Jurnal Riset Akuntansi Indonesia, 3(2). Retrieved from https://eprints.ums.ac.id/5368/1/B200050208.pdf. Accessed on March 21, 2020

Romney, \& Steinbart. (2012). Accounting Information System. (12th Edition). London: Prentice Hall.

Samosir, S. (2018). Analisis Faktor-Faktor yang Mempengaruhi Kualitas Informasi Laporan Keuangan Pemerintah Daerah dan Efektivitas Sistem Informasi Akuntansi sebagai Variabel Moderasi. Universitas Lampung Bandar Lampung. Retrieved from http://digilib.unila.ac.id/55315/3/3. SKRIPSI FULL TANPA BAB PEMBAHASAN.pdf. Accessed on March 21, 2020

Sanders, G. L., \& Courtney, J. F. (1985). A Field Studi Organizational Factors Influencing DSS Success. MIS Quarterly, 9(1), 77-92. Retrieved from https://misq.org/a-field-study-of-organizational-factorsinfluencing-dss-success.html. Accessed on March 21, 2020

Soegiharto. (2001). Influence Factors Affecting The Performance of Accounting Information Systems. Gajah Mada International Journal of Business, 3(2), 177-202. Retrieved from https://www.academia.edu/19803755/The_Influence_of_Information_System_User_Competency_and_T he_Quality_of_Management_Accounting_Information_Systems_on_User_Satisfaction. Accessed on March 21,2020

Sugiyono. (2014). Metode Penelitian Pendidikan Pendekatan Kuantitatif, Kualitatif, dan R\&D. Bandung: Alfabeta.

Sukmaningrum, T. (2012). Analisis Faktor-Faktor yang Mempengaruhi Kualitas Laporan Keuangan Pemerintah Daerah (Studi Empiris pada Pemerintah Kabupaten dan Kota Semarang). Universitas Diponegoro Semarang. Retrieved from http://eprints.undip.ac.id/35305/1/Skripsi_15.pdf. Accessed on March 21, 2020

Susanto. (2013). Sistem Informasi Akuntansi. Jakarta: Gramedia.

Widaninggar, N. (2013). Value Added Implementasi Enterprise Resource Planning (ERP). Jurnal Akuntansi Dan Manajemen, 10(2), 306-317. Retrieved from http://manajemen.upy.ac.id/manajemen/wpcontent/uploads/2016/12/Value-Added-Implementasi-Enterprise-Resource-Planning-ERP.pdf. Accessed on July 8, 2019

Widjajanto, N. (2001). Sistem Informasi Akuntansi. Jakarta: Erlangga.

Yaverbaum, G. M., \& Nosek, J. (1992). Effects of Information System Education and Training on User Satisfaction. Information and Management, 22(4), 217-225. Retrieved from https://vdocuments.net/ effects-of-information-system-education-and-training-on-user-satisfaction.html. Accessed on March 21 , 2020. 